\title{
DISTINCTIVENESS OF TERMITE ASSEMBLAGES IN TWO FRAGMENTED FOREST TYPES IN HANTANE HILLS IN THE KANDY DISTRICT OF SRI LANKA
}

\author{
I. I. Hemachandra ${ }^{1,2 *}$, J. P. Edirisinghe ${ }^{1}$, W. A. I. P. Karunaratne ${ }^{1}$ and C.V.S. Gunatilleke ${ }^{3}$ \\ ${ }^{1}$ Department of Zoology, Faculty of Science, University of Peradeniya, Sri Lanka \\ ${ }^{2}$ Postgraduate Institute of Science, University of Peradeniya, Sri Lanka \\ ${ }^{3}$ Department of Botany, Faculty of Science, University of Peradeniya, Sri Lanka \\ Accepted 27 May 2010
}

\begin{abstract}
This study compares the termite assemblages in a natural and a secondary forest located at two different elevations in the Hantane hills, a tropical evergreen forest in mid country Sri Lanka, with a view to identify their distinctiveness. To sample the termites in the two forest types the belt transect method was used supplemented by random collections. A total of 11 species of termites in four genera belonging to three subfamilies and one family, Termitidae were recorded; nine species from the secondary forest and two species from the natural forest. The two species, Ceylonitermellus hantanae and Dicuspiditermes incola showed a distinct distribution in being confined only to the natural forest at high elevation. Termites recorded were put into feeding groups based on their taxonomic identity. Termites of the natural forest were found to be exclusively true soil feeders. Those of the secondary forest were wood feeders; either fungus growing $(8 \mathrm{spp}$.) or non-fungus growing wood feeders $(1 \mathrm{sp}$.$) . The high abundance and low$ diversity of the natural forest termite species in comparison to secondary forest species also make them distinct. Elevation, climate, vegetation, ground cover and the degree of human interference appear to contribute to the distinctiveness of termite assemblages in the two forests types reported here.
\end{abstract}

Key words: natural forest, secondary forest, species diversity, functional groups, elevation

\section{INTRODUCTION}

The Asian tropical forests are known for their rich fauna, particularly the termites due to the role they play in the recovery of forest ecosystems (Davies et al., 1999). Termites, as dominant arthropod detritivores, are important in decomposition processes. The termite assemblages in forests are very sensitive to habitat disturbances like fire, forest clearance (Davies, 1997; Davies et al., 2003; Eggleton et al., 1995, 1996), canopy loss (Gathrone-Hardy et al., 2001) and forest fragmentation (Davies et al., 2003).

Studies conducted in Southeast Asia have reported the richness of termite species in dry deciduous dipterocarp forests of Thailand (Davies, 1997), where 16 species of soil, wood and fungus feeding termites have been documented. Eggleton et al. (1997) reported 92 species of termites from the Danum valley in Malaysia, and 29 species have been reported from the Pasoh forest in Malaysia (Morimoto, 1976; Abe, 1978; Abe and Matsumoto, 1979; Tho, 1982; Jones and Brandel, 1998). The largest assemblage of termites from tropical Asia, numbering 102 species, is reported from the Leuser Ecosystem in Indonesia (GathoneHardy et al., 2001).

For the Indian sub region as a whole, comprising India, Pakistan, Nepal, Bhutan, Bangladesh, Burma and Sri Lanka, 337 species of termites in 59 genera have been listed and comprehensively described by Roonwal and Chhotani (1989) and Chhotani (1997). Bose (1984) reported 95 species of termites in five families and their distribution in Southern India. A study conducted in Western Ghats in Southern India on the termite community and the impact of anthropogenic disturbances recorded 12 species of termites representing nine genera in three subfamilies in the family Termitidae. Our recently prepared checklist of termites from Sri Lanka, based on published literature on termites, reports 64 species in 27 genera and awaits publication. Early records on termites from Sri Lanka reported 57 species (Snyder, 1949) and 58 species (Sands, 1975). With respect to forest termites of Sri Lanka, the only available literature is a study by Green

*Corresponding author's email: iindujinah@yahoo.com 
(2005) on termites in Himbiliyake forest reserve near Wasgamuwa, (Pollanaruwa District in the North Central Province) from where nine species of termites in the two families Termitidae and Rhinotermitidae have been recorded. The area of natural forests in Sri Lanka is rapidly decreasing and a majority of the remaining forests are fragmented and degraded due to both legal and illegal wood extraction (Gunatilleke and Gunatilleke, 1990). Here, we report the diversity and species composition of termites in two fragmented tropical evergreen forests in the Hantane hills of Kandy (Central Province). The two fragmented forests comprise a natural forest and a secondary forest about $3 \mathrm{~km}$ apart, from where termites were examined by random collections and the belt transect sampling method.

\section{MATERIALS AND METHODS}

\section{Forest sites}

The Hantane forest range is situated in the wet zone of Sri Lanka at approximately $7^{\circ} 17^{\prime}$ $\mathrm{N}$ and $80^{\circ} 36^{\prime} \mathrm{E}$. It extends over an area of 432 ha. The forest consists of a series of hills separated by valleys at elevations ranging from $518-1110 \mathrm{~m}$. The area is characterized by hot, humid and sub-temperate climate (Greller et al., 1980). The mean annual temperature is $24.1^{\circ} \mathrm{C}$ and the mean annual precipitation is $2,121 \mathrm{~mm}$. The average annual precipitation for the period of 1999 to 2009 was $1924.2 \mathrm{~mm}$ (data from Natural Resource Management Centre, Peradeniya). Rain is received from both the Southwest and Northeast monsoons and is evenly distributed throughout the year. During the British Colonial Period, lower and upper lands of Hantane forest were opened up first for coffee and later for tea and rubber plantations. When the major part of the land was acquired by the University of Peradeniya in 1946, most parts of the land were devoid of natural vegetation. A few Pinus plantations were established in 1980. Restoration of plant diversity in Pinus plantations in Lower Hantane was initiated in 2002 (Ambagahaduwa, 2008). At present, six vegetation types can be identified in Hantane hills. They are: Albizia woodland $(12.5 \%$, introduced as a shade tree for tea), Alstonia woodland (5\%), mixed species woodland (18\%), Pinus woodland (23\%), Patana grasslands $(39.5 \%)$ and patches of undisturbed natural forest (2\%) (Ratnayake, 2001). This study examines the termite assemblages in patches of undisturbed natural forest (Fig.1) at an elevation of $>900 \mathrm{~m}$ and a disturbed secondary forest in the mixed species woodland (Fig. 2) at elevations between 700$900 \mathrm{~m}$.

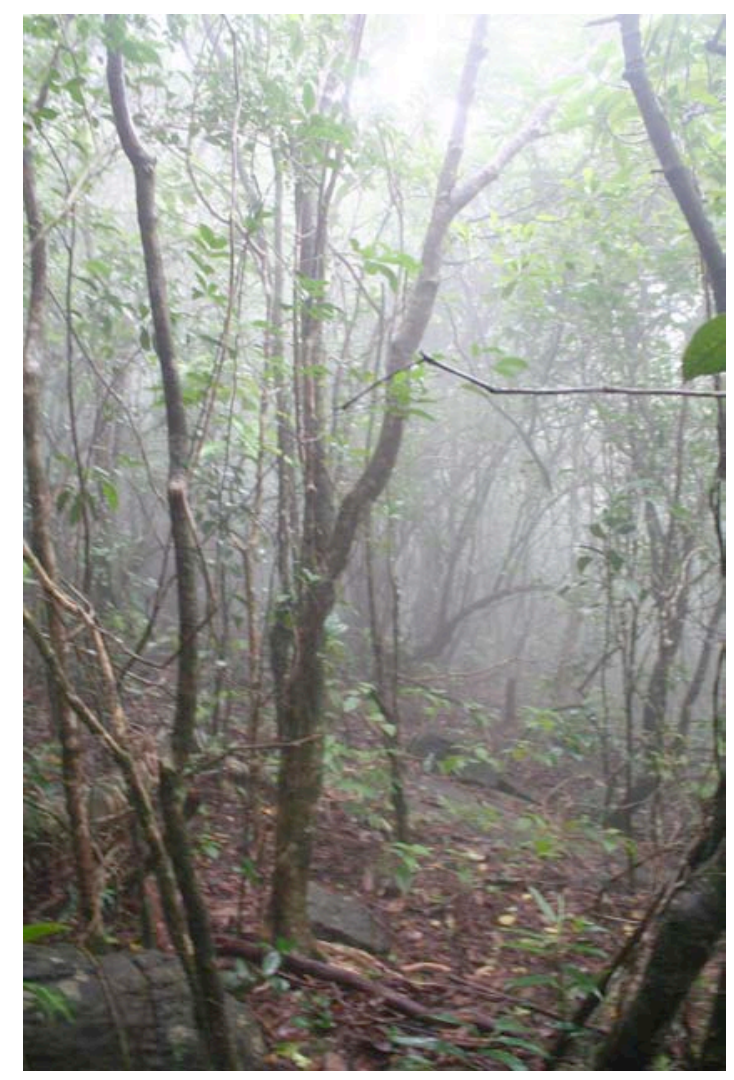

Figure 1. Section of the natural forest in Hantane hills, Kandy.

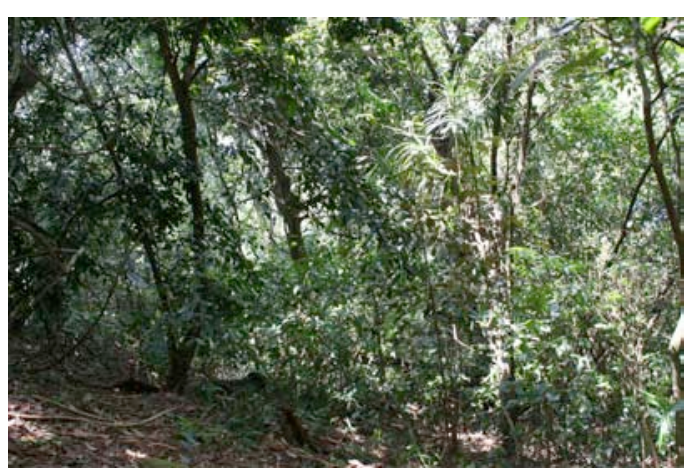

Figure 2. Section of the mixed species woodland representing the secondary forest in Hantane hills, Kandy.

\section{Sampling of termites}

Standardized transect method of Jones and Eggleton (2000) was used for sampling termites. A belt transect $(2 \times 100 \mathrm{~m})$ was laid in each forest. Each transect was divided into 20 (2 $\mathrm{x} 5 \mathrm{~m}$ ) sections and in each section one manhour was spent searching for termites. Within each section the following microhabitats were searched; surface soil (12 samples, each about 
$12 \times 12 \mathrm{~cm}$, to $10 \mathrm{~cm} \mathrm{depth),} \mathrm{leaf} \mathrm{litter} \mathrm{and}$ humus on the forest floor (at the base of trees, between buttress roots etc.), inside dead logs, tree stumps, branches, twigs, subterranean nests, mounds, carton sheetings and runways on trees up to a height of $2 \mathrm{~m}$ above ground and arboreal nests up to $2 \mathrm{~m}$ height. Mainly soldier and worker castes were collected from the different microhabitats, while alates were collected only from nests. The number of encounters with termites (hits) of a given species within a transect was taken as the relative abundance of that species within that transect. An encounter is the presence of a species in one transect section (5 $\mathrm{x} 2 \mathrm{~m})$. Termite diversity was compared using Shannon Diversity Index. In addition to sampling, random collections of termites were carried out in several areas within the two forest types for species determination. Termite specimens collected for identification were stored in $80 \%$ isopropyl alcohol.

Termite nests encountered were examined and recorded both during sampling and random collections. Nest type of termites whose nests were not encountered during the study was determined on the basis of species identity, using information given in Bose (1984) and Roonwal (1970).

Recorded termites were placed in to feeding groups based on their identity, using the classification of Donovan et al. (2001).

\section{RESULTS}

\section{Species composition and distribution in the two forest types}

Termites collected from the two forests types belonged to a single family, Termitidae, and were represented by three subfamilies and four genera (Table 1). A total of 11 morphospecies were identified; six to species level and five to generic level (Genus Odontotermes). The identified six species are Nasutitermes fletcheri (Holmgren \& Holmgren), Ceylonitermellus hantanae (Holmgren) (Fig. 3), Dicuspiditermes incola (Wasmann), Odontotermes horni (Wasmann), O. globicola (Wasmann), and O. ceylonicus (Wasmann) (Table 1). The identities of these six species were confirmed using keys, descriptions and measurements given in Roonwal and Chhotani (1989) and Chhotani (1997).

A distinct difference in the species composition of termites in the two forest types was seen. In the natural forest only two species, C. hantanae and D. incola, were present. Both species were recorded from transect as well as from random collections. These two species were not found in the secondary forest, from where a total of 9 species, 8 species of Odontotermes and Nasutitermes fletcheri, were recorded. Of the nine termite species found in the secondary forest, four species were collected from transect, three from random collections and two (Odontotermes horni and Odontotermes sp. 2) from both transect and random collections (Table 1).

\section{Termite species diversity}

Transect sampling involving 20 sections per transect where 20 man hours were spent in each transect, enabled the comparison of termite diversity in the two forest types. Species diversity index calculated using Shannon Diversity Index gave a value of $\mathrm{H}^{\prime}=1.630$ for the secondary forest, which was much higher compared to the natural forest $\left(H^{\prime}=0.683\right)$

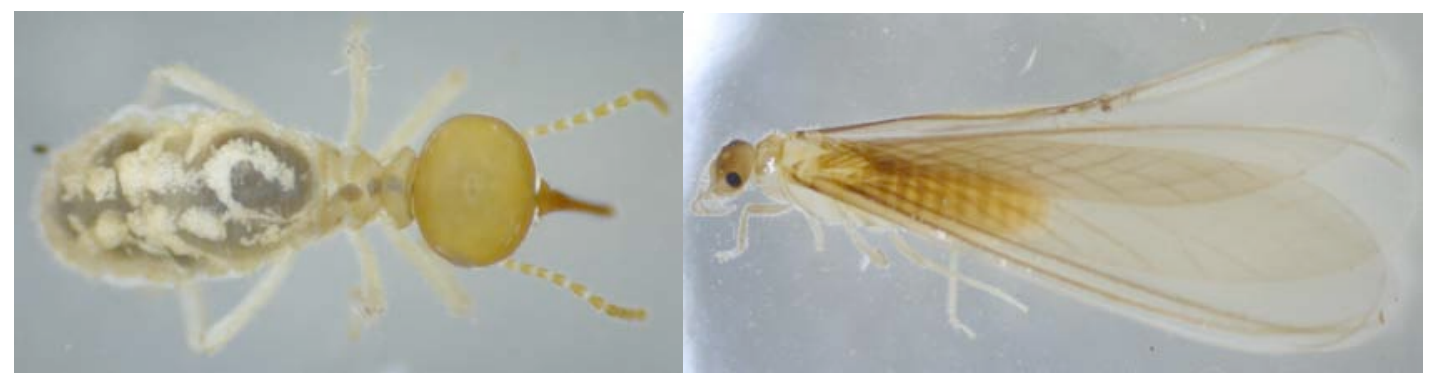

Figure 3. The endemic termite Ceylonitermells hantanae (a) soldier caste (b) winged reproductive (alate). 


\section{Termite feeding groups}

The termite species identified from the study sites belonged to two distinct feeding groups (Table 1) according to the classification of Donovan et al. (2001), based on mandible features. The feeding group I that includes lower termites was not represented in either of the two forest types in the Hantane hills. Similarly, termites of the feeding group III, represented by organic rich soil feeders, were absent from both types of forests in the Hantane hills. According to the feeding group classification, termites of the feeding group II which are wood feeders represented by fungus growing and non-fungus growing wood feeders were present only in the secondary forest. Feeding group IV termites that are true-soil feeders were confined to the primary forest. The feature of the right mandible molar plate of $C$. hantanae, where there were no ridges, was used to place this endemic species in the feeding group IV of Donovan et al. (2001). Thus, the majority of the secondary forest termite species, according to the feeding group classification are fungus growing wood feeding species, while the two natural forest species are 'True soil feeders' (Fig. 4).

\section{Species accumulation curve}

From the data gathered on termites in the 20 sections of transect in each forest type, a species accumulation curve was plotted (Fig. 5). The curve reached a plateau at the $5^{\text {th }}$ transect section in the natural forest (Fig. 5) suggesting that no further increase in species would be encountered with an increase in the area sampled. In contrast, the rising species accumulation curve for the secondary forest suggests that yet more species await collection and identification, with further sampling effort.

\section{Termite abundance}

The relative abundance levels based on number of hits per transect indicated that the endemic species $C$. hantanae and the native $D$. incola inhabiting the natural forest have high abundance levels versus the several Odontotermes species in the secondary forest (Fig. 6).

Table 1. Details of termite taxa recorded from the two forest types in Hantane.

\begin{tabular}{|c|c|c|c|c|}
\hline Termite Taxa & $\begin{array}{l}\text { Forest } \\
\text { Type }\end{array}$ & $\begin{array}{l}\text { Method of } \\
\text { Collection }\end{array}$ & $\begin{array}{l}\text { Feeding } \\
\text { group }\end{array}$ & $\begin{array}{l}\text { Nesting } \\
\text { group }\end{array}$ \\
\hline \multicolumn{5}{|l|}{ Family TERMITIDAE } \\
\hline \multicolumn{5}{|l|}{$\begin{array}{l}\text { Subfamily } \\
\text { Nasutitermitinae }\end{array}$} \\
\hline Nasutitermes fletcheri & Secondary & $\mathrm{R}$ & $\mathrm{II}(\mathrm{NF})$ & 2 \\
\hline $\begin{array}{l}\text { Ceylonitermellus } \\
\text { hantanae }\end{array}$ & Natural & $\mathrm{T}, \mathrm{R}$ & IV & 1 \\
\hline $\begin{array}{l}\text { Subfamily Termitinae } \\
\text { Dicuspiditermes incola }\end{array}$ & Natural & $\mathrm{T}, \mathrm{R}$ & IV & 1 \\
\hline \multicolumn{5}{|l|}{$\begin{array}{l}\text { Subfamily } \\
\text { Macrotermitinae }\end{array}$} \\
\hline Odontotermes horni & Secondary & $\mathrm{T}, \mathrm{R}$ & $\mathrm{II}(\mathrm{F})$ & 1 \\
\hline O. globicola & Secondary & $\mathrm{T}$ & $\mathrm{II}(\mathrm{F})$ & 1 \\
\hline O. ceylonicus & Secondary & $\mathrm{R}$ & $\mathrm{II}(\mathrm{F})$ & 1 \\
\hline Odontotermes sp.1 & Secondary & $\mathrm{T}$ & $\mathrm{II}(\mathrm{F})$ & 1 \\
\hline Odontotermes sp. 2 & Secondary & $\mathrm{T}, \mathrm{R}$ & $\mathrm{II}(\mathrm{F})$ & 1 \\
\hline Odontotermes sp. 3 & Secondary & $\mathrm{T}$ & $\mathrm{II}(\mathrm{F})$ & 1 \\
\hline Odontotermes sp.4 & Secondary & $\mathrm{T}$ & $\mathrm{II}(\mathrm{F})$ & 1 \\
\hline Odontotermes sp.10 & Secondary & $\mathrm{R}$ & $\mathrm{II}(\mathrm{F})$ & 1 \\
\hline
\end{tabular}

(Method of collection: $\mathrm{R}=$ random collection, $\mathrm{T}=$ transect sampling)

(Feeding groups: II = wood feeders, $\mathrm{IV}=$ true soil feeders, $\mathrm{NF}=$ non-fungus growing, $\mathrm{F}=$ fungus growing)

(Nesting groups: $1=$ subterranean, $2=$ arboreal) 


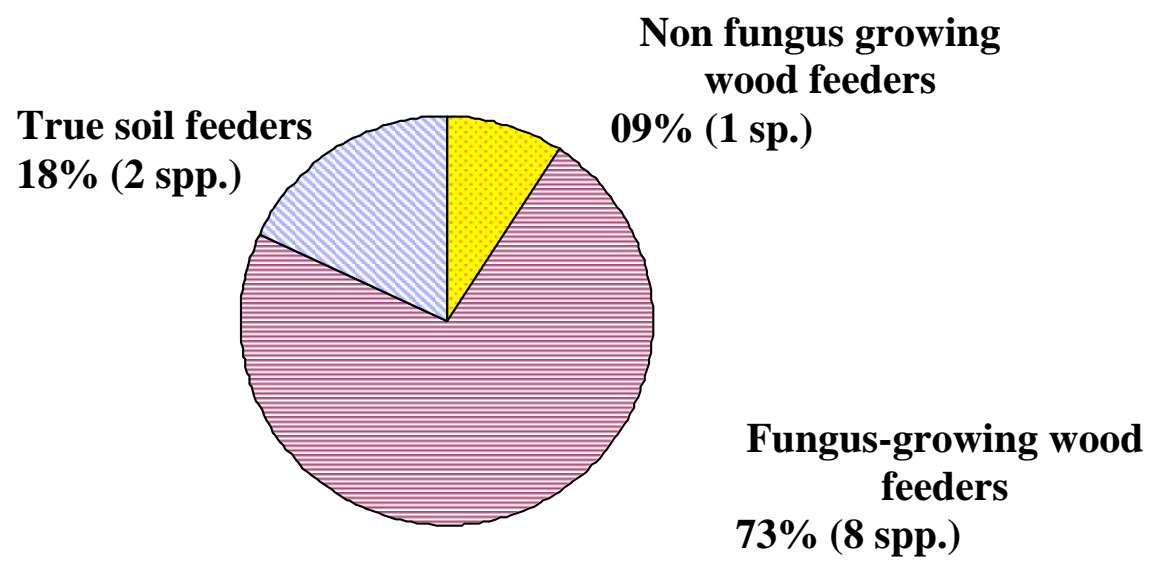

Figure 4. Proportion of termite species per feeding group in the two forest types in Hantane hills. (Data from transect sampling and random collections).

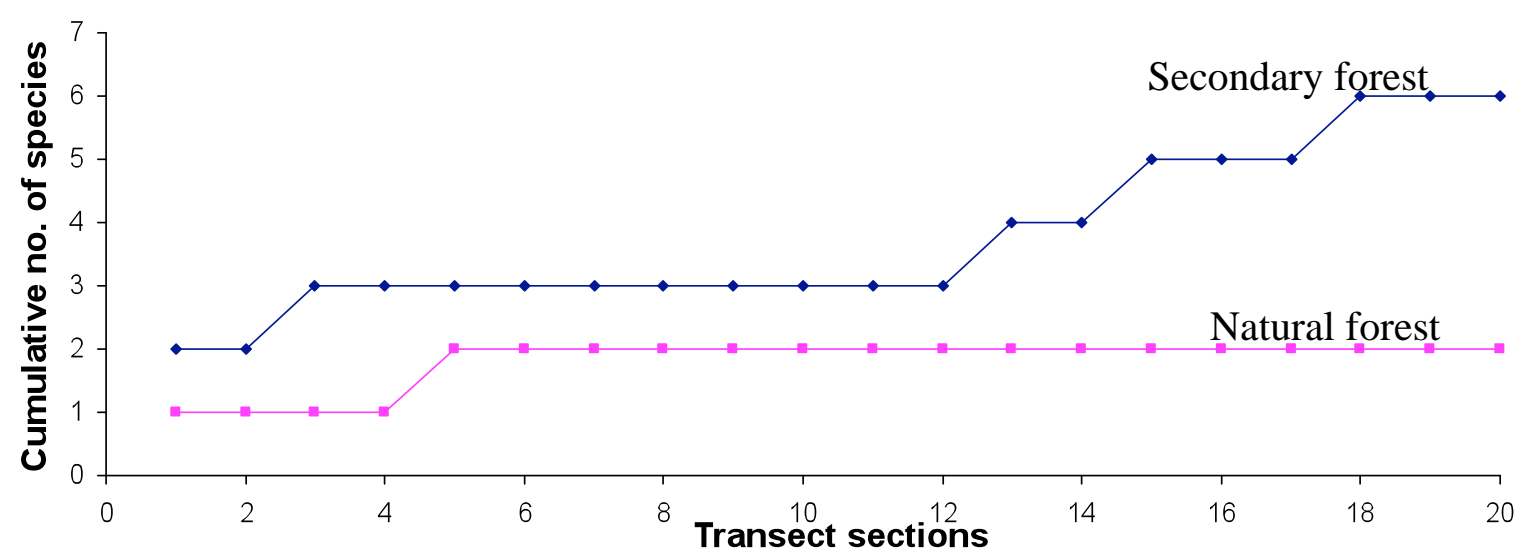

Figure 5. Termite species accumulation curves in the transects sampled in two different forest types in the Hantane hills.

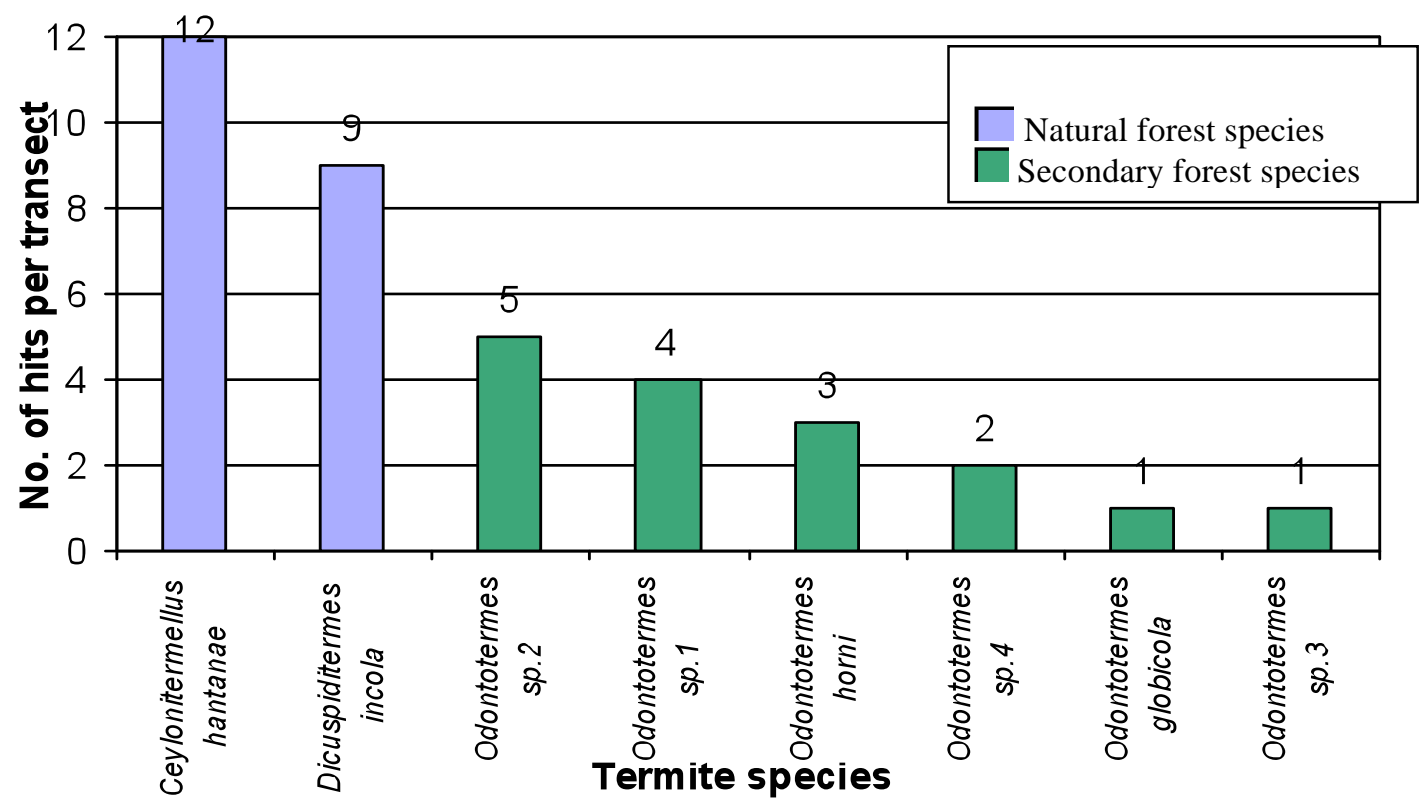

Figure 6. Abundance of termite species in the two forest types sampled in Hantane hills. 


\section{Nesting groups of termites}

Nests of termite species inhabiting the natural forest were observed during both transect sampling and random collections. Subterranean nests of $C$. hantanae and $D$. incola were encountered in subsurface soil at about 10 $\mathrm{cm}$ depth, and all the developing stages together with the different castes were present in these nests. Nests of the remaining termite species inhabiting the secondary forest were not encountered. However, the nest type of these four identified termite species was inferred on the basis of information given in Bose (1984) and Roonwal (1970). Accordingly, all of the identified termite species (6 spp.) except one are subterranean nesters. Nasutitermes fletcheri is the only arboreal nester (Table 1)

\section{DISCUSSION}

The distinct species composition of termites with only two species inhabiting the fragmented natural forest is an interesting finding. Of the two species, $C$. hantanae is endemic to Sri Lanka and was first recorded in 1911 from Hantane, which is also its type-locality (Chhotani, 1997). This species has not been recorded since from the island until the present study. Even in this study it was recorded only from the natural forest located at high elevation that is subjected to frequent fires that spread from the adjacent grassland. Invasion by the exotic plant Clusia rosea is also a recent threat to this natural forest.

Of the nine species recorded from the secondary forest, only $N$. fletcheri is a new record for Sri Lanka. It has been previously recorded only from India (Chhotani, 1997). Its identity was confirmed on the basis of features given in Chhotani (1997).

The differences in species composition and distribution of termites observed between the two forest types can be attributed to several factors among which habitat disturbance in the secondary forest is a key factor. The fragmented secondary forest is separated from patches of the natural forest by grasslands and Pinus plantations. These grasslands and the Pinus litter are fire prone as there is a tendency by local inhabitants to frequently set fire to the grasslands to facilitate new growth for cattle grazing. This practice is important in maintaining regeneration in the grassland community.

The distinctiveness of the termite assemblages in the natural forest can be attributed to the lower montane conditions relating to altitude, climate and vegetation. Several studies have shown that termite species diversity and richness decrease with increase in altitude (Gathorne-Hardy et al., 2001; Jones, 2000; Collins, 1980; Donovan et al., 2002; Inoue et al., 2006). Furthermore, environmental temperature decreases with altitude. Maintenance of a fairly constant environmental temperature is important for the survival of termite colonies (Korb and Linsenmair, 1998). These factors act differentially on different termite clades (Donovan et al., 2002). Therefore, only certain species are able to survive at the lower temperatures that prevail at higher altitudes. Low temperature negatively affects the active foraging habit, particularly of the wood feeding termite subfamily Macrotermitinae (Donovan et al., 2002) and the growth of their fungus cultivations (Inoue et al., 2006). This explains the absence of Odontotermes species in the natural forest situated at a higher elevation. On the other hand, at lower altitudes the majority of the secondary forest termites comprised Odontotermes species.

The high abundance of the two termite species (based on the number of hits per species in a transect) in the natural forest compared to those in the secondary forest may be attributed to several factors. The most significant feature among them is that the two abundant natural forest species come under the feeding group IV that includes true soil feeders. The absence of termites of the feeding group II, which are wood feeders, from the natural forest located at high altitude (900 $\mathrm{m}$ or above) is noteworthy. With respect to the distribution of termite feeding groups at different altitudes, Gathorne-Hardy et al, (2001) have demonstrated that group II termites (wood feeders) decreases significantly with increasing altitude. In our study too, group II feeders were confined to the lower altitude secondary forest and were absent from the natural forest. Termites of the feeding group II are known to be active foragers moving from their subterranean or arboreal nests to high energy wood resources.

A distinct difference in the foraging habits of the subterranean termite species in the natural and secondary forest is evident. The natural forest termite species not only nests in soil but also feeds on soil. On the contrary, the secondary forest subterranean species that nest in soil forage above ground in dead wood (fallen branches and trunks of trees) making runways from their nesting site to the foraging site. The arboreal nesting species in the 
secondary forest similarly make runways in search of dead wood on ground to forage.

The vegetation in natural forest is dominated by species such as endemic Strobilanthus sp., Toddalia asiatica, Neolitsea cassia, Melicope lunu-ankenda and Symplocos cochinchinensis. The secondary forest is dominated by large woody shade trees of the former tea plantations such as Alstonia macrophylla and Albizia falcataria and economically important species such as Semecarpus obscura, Michelia champaca, Nothopegia beddomi, Artocarpus heterophyllus and Artocarpus nobilis. Invasive Clusia rosea is becoming a threat to both forests as it is expanding its range to the exclusion of other species.

Accompanying the variation in the plant species composition is the differences in leaf litter distribution in the two forest types. The ground litter layer in the natural forest was relatively sparse but with higher moisture content. In contrast, the secondary forest ground cover was more complex, was much more heterogeneous and comparatively dry with obvious signs of termite activity, which was lacking in the ground cover of the natural forest. In the secondary forest the woody litter comprised mainly larger diameter branches, while that in the natural forest is of pencil size woody twigs and smaller branches.

The species accumulation curve provides a means of assessing sampling efforts with species turn over. In describing the sampling protocol by Jones and Eggleton (2000) a section of a transect was considered as a unit sampling effort. The same criterion has been used in interpreting the findings of this study.

In drawing conclusions from this preliminary study two problems were encountered. One of them stems from limited sampling carried out during this preliminary investigation, which would be extended to a couple of more transects as the study progresses. However, a previous study conducted by Jones and Eggleton (2000) to test the belt transect protocol has concluded that each transect captures approximately $31-36 \%$ of the known local termite fauna in a given site. A study on termite fauna in a 50 hectare plot of Pasoh forest, Malaysia, used only three transects (Jones and Brendel, 1998), while a study in Indonesia in the Sungai Tabalong Kiwa area used only one transect for each of the four sites (Jones and Prasetyo, 2002).
The other problem encountered in the study is the confounding factor due to a particular elevation and forest type not occurring together. Due to the manner in which the two forest types occur, where the natural forest is limited to high elevations and the secondary forest to lower elevations, it is not possible to dissociate forest type from elevation. Unless sampling is carried out along an elevation gradient in the Hantane hills, spanning across both forest types, the confounding factor cannot be addressed. A similar confounding factor was encountered in the study by Gathorne-Hardy et al, (2001) where nine different study sites representing five different forest types were located at 12 different altitudes

This preliminary study highlights the distinctiveness of the natural forest termite assemblage in the Hantane hills where altitude, vegetation, ground cover, lower montane climatic conditions and the relatively low human interference have helped to preserve its uniqueness. Sampling in progress at this site would further confirm the distinctiveness of the species encountered. Furthermore, work in different natural forests, at different elevation and climatic conditions are advocated to test the uniqueness of natural forest termites reported here.

\section{ACKNOWLEDGEMENTS}

We are grateful to Dr. S. Batra, formally of USDA Beltsville for providing funds for this study, Mr. Pradeep Samarawickrama for field assistance and photographs, Department of Wildlife Conservation and the Forest Department of Sri Lanka for granting permission to collect specimens and work at different sites and Mr. Niroshan Samarasinghe of the Department of Zoology for photographing the specimens.

\section{REFERENCES}

Abe, T. (1978). Studies on the distribution and ecological role of termites in a lowland rain forest of west Malaysia. I. Faunal composition, size, coloration and nest of termites in Pasoh Forest Reserve. Kontyu 46: 273-290

Abe, T. and Matsumoto, T (1979). Studies on the distribution and ecological role of termites in a lowland forest of west Malaysia. III. Distribution and abundance of termites in Pasoh Forest Reserve. Japanese Journal of Ecology 29:337-351 
Ambagahaduwa, I. M. (2008). Restoration of plant diversity in a Monoculture Pinus Plantation in Lower Hantane, Sri Lanka M. Phil. thesis. University of Peradeniya. Sri Lanka.

Bose, G. (1984) Termite fauna of Southern India. Records of Zoological Survey of India. Zoological Survey of India. Calcutta. Pp. 270.

Chhotani, O. B. (1997). Isoptera (Termites). Vol.II (Family Termitidae). The fauna of India and the adjacent countries. Zoological Survey of India. Pp. 800

Collins, N. M. (1980). The distribution of soil microfauna on the west ridge of Gunung (Mount) Mulu, Sarawak. Oecologia (Berlin) 44: 263-275.

Davies, R. G. (1997). Termite species richness in fire-prone and fire protected dry deciduous dipterocarp forest in Doi Suthep-Pui National Park, northern Thailand. Journal of Tropical Ecology 13: 153-160.

Davies, R. G., Eggleton, P. Dibog, L., Lawton, J. H., Bignell, D. E., Brauman, A., Hartmann, C., Nunes, L., Holt, J. and Rouland, C. (1999). Successional response of a tropical forest termite assemblage to experimental habitat perturbation. Journal of Applied Ecology 36(6): 946-962.

Davies, R. G., Hernández, L. M., Eggleton, P., Didham, R. K., Fagan, L. L. and Winchester, N. N. (2003). Environmental and spatial influences upon species composition of a termite assemblage across neotropical forest islands. Journal of Tropical Ecology 19: 509-524.

Donovan, S. E., Eggleton, P. and Bignell, D. E. (2001). Gut content analysis and a new feeding group classification of termites (Isoptera). Ecological Entomology 26: 356-366.

Donovan, S. E., Eggleton, P. and Martin, A. (2002). Species composition of termites of the Nyika plateau forests, northern Malawi, over an altitudinal gradient. African Journal of Ecology 40: 379-385.

Eggleton, P., Bignell, D. E., Sands, W. A., Mawdsley, N. A., Lawton, J. H.,Wood T. G. and Bignell, N. C. (1996). The Diversity, abundance and biomass of termites under differing levels of disturbance in the Mbalmayo Forest Reserve, Southern Cameroon. Philosophical Transactions of the Royal Society of London. Ser. B. Biological sciences 351: 5168.

Eggleton, P., Bignell, D. E., Sands, W. A., Waite, B., Wood, T. G. and Lawton, J. H. (1995). The species richness of termites (Isoptera) under differing levels of forest disturbance in the Mbalmayo Forest Reserve, southern Cameroon. Journal of Tropical Ecology 11: 85-98.

Eggleton, P., Homathevi, R., Jeeva, D., Jones, D. T., Davies, R. G. and Maryati, M. (1997). The species richness and composition of termites (Isoptera) in primary and regenerating lowland dipterocarp forest in Sabah, East Malaysia. Ecotropica 3: 119-128

Gathorne-Hardy, F. Syaukani \& Eggleton, P. (2001). The effect of altitude and rainfall on the composition of termites (Isoptera) of the Leuser Ecosystem (Sumatra, Indonesia). Journal of Tropical Ecology 17: 379-393.

Green, D. (2005). A preliminary study of forest termite diversity in central Sri Lanka (Himbiliyake Forest Reserve) using a new sampling technique. A report of Sri Lanka Wildlife Conservation Society.

Greller, A. M., Gunatilleke, C. V. S., Gunatilleke, I. A. U. N. and Balasubramanium, S. (1980). A phytosociological analysis of three strands of forests in the vicinity of Peradeniya, Kandy district. The Sri Lanka Forester 14 $(3,4): 153-161$.

Gunatilleke, I. A. U. N. and Gunatilleke, C. V. S. (1990). Distribution of floristic richness and its conservation in Sri Lanka. Conservation Biology 4(1): 21-31

Inoue, T., Takematsu, Y., Yamada, A., Hongoh, Y., Johjima, T., Moriya, S., Sornnuwat, Y., Vongkaluang, C., Ohkuma, M., and Kudo, T. (2006). Diversity and abundance of termites along an altitudinal gradient in Khao Kitchagoot National Park, Thailand. Journal of Tropical Ecology 22(5): 609-612

Jones, D. T. (2000). Termite assemblages in two distinct montane forest types at $1000 \mathrm{~m}$ elevation in the Maliau Basin, Sabah. Journal of Tropical Ecology 16: 271286.

Jones, D. T. and Brendell, M. J. D. (1998). The termite (Insecta: Isoptera) fauna of Pasoh Forest Reserve, Malaysia. Raffles Bulletin of Zoology 46 (1):79-91. 
Jones, D. T. and Eggleton, P. (2000). Sampling termite assemblages in tropical forests: testing a rapid biodiversity assessment protocol. Journal of Applied Ecology 37: 191-203.

Jones, D. T. and Prasetyo A. H. (2002). A survey of termites (Insecta: Isoptera) Tabalong District, South Kalimenan, Indonesia. Raffles Bulletin of Zoology 50(1):117-128.

Korb, J. and Linsenmair, K. E. (1998). The effects of temperature on the architecture and distribution of Macrotermes bellicosus (Isoptera, Macrotermitinae) mounds in different habitats of a West African Guinea savanna. Insectes sociauxSociaux 45: 51-65.

Morimoto, K. (1976). Termites from Malaya. Nature and Life in Southeast Asia 7: 323-326

Ratnayake, R. M. C. S. (2001). Floristics and nutrient status of Hantane forests, Sri Lanka. M.Phil. thesis. University of Peradeniya. Sri Lanka.
Roonwal, M. L. (1970). Termites of the oriental region. Biology of Termites. Vol. II (Ed. Krishna, K. and Weesner, F. M.), Academic Press. Iinc. New York and London. Pp. 315-391

Roonwal, M. L. and Chhotani, O. B. (1989). Isoptera (Termites). Vol. I. The fauna of India and the adjacent countries. Zoological Survey of India. Pp. 672.

Sands, W. A. (1975). Visit to Sri Lanka to study termite (Kalotermitidae) damage to tea 12-18 October 1975. Country Visit Report No. CVR/76/1. Centre for overseas Pest Research (COPR). London U.K. Ppp. 27.

Snyder, T. E. (1949). Catalog of Termites (Isoptera) of the worldWorld. Smithson. Misc. Collect. 112 (3595): 1-490.

Tho, Y. P. (1982). Studies on the taxonomy and biology of termites (Isoptera) of Peninsular Malaysia. PhD thesis. University of Aberdeen. Aberdeen. UK. 